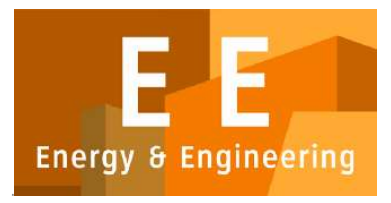

PAPER - OPEN ACCESS

\title{
Kearifan Lokal Arsitektur Masjid Demakan
}

\author{
Author : Mohhamad Kusyanto \\ DOI $\quad: 10.32734 /$ ee.v3i1.854 \\ Electronic ISSN : :2654-704X \\ Print ISSN : $2654-7031$
}

Volume 3 Issue 1 - 2020 TALENTA Conference Series: Energy \& Engineering (EE)

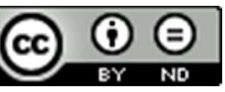

This work is licensed under a Creative Commons Attribution-NoDerivatives 4.0 International License.

Published under licence by TALENTA Publisher, Universitas Sumatera Utara

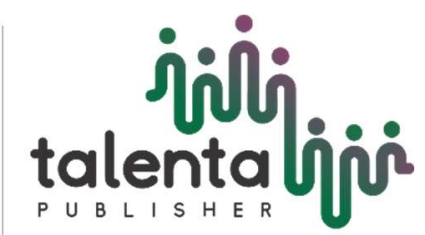




\title{
Wibi \\ EE Conference Series 03 (2020)

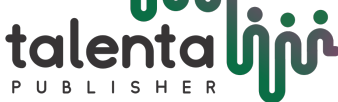

P U B L I S HER

\section{Kearifan Lokal Arsitektur Masjid Demakan}

\author{
Local Wisdom on theArchitecture of Demakan Mosque
}

\author{
Mohhamad Kusyanto* \\ Program Studi Arsitektur Universitas Sultan Fatah, Jl. Raya Katonsari No.19, Demak Jawa Tengah Indonesia 59516 \\ mkusyanto@gmail.com
}

\begin{abstract}
Abstrak
Penelitian ini dilatarbelakangi dari keberadaan Masjid Agung Demak merupakan masjid pertama di Kabupaten Demak. Masjid ini telah berdiri sejak tahun $1479 \mathrm{M}$ ini memiliki arsitektur masjid yang unik. Keunikan arsitektur masjid ini dilakukan penelitian lebih mendalam sehingga sehingga menjadi rujukan dalam membangun masjid lain di Kabupaten Demak. Arsitektur masjid ini telah terjaga kearifan lokalnya hingga berdiri sampai sekarang ini. Tujuan penelitian ini untuk mengidentifikasi, merumuskan arsitektur masjid Demakan sebagai salah satu arsitektur masjid yang dilestarikan di Kabupaten Demak. Metode yang digunakan dalam penelitian ini adalah metode kualitatif deskriptif. Metode pengumpulan data dilakukan dengan cara pengamatan di lapangan. Penelitian ini menggunakan pendekatan kualitatif dan merupakan penelitian eksploratif. Jenis penelitian bersifat deskriptif yakni menganalisa dan menyajikan fakta secara sistematik sehingga mudah untuk dipahami dan disimpulkan. Adapun pengambilan data dilakukan secara observasi, wawancara mendalam pada sejumlah responden, dan penelusuran pustaka. Hasil penelitian dapat dirumuskan bahwa kearifan lokal arsitektur masjid Demakan meliputi : (1) tata ruang yakni ruang utama salat, serambi dan ruang tambahan lain; (2) Struktur ditopang 4 saka guru dan 12 saka penanggap pada ruang utama salat dan struktur ditopang 8 saka guru dan 28 saka penanggap pada ruang serambi; dan (3) Ruang utama salat berbentuk bujur sangkar dengan atap tajug tumpang tiga dan serambi berbentuk persegi panjang dengan atap limasan. Arsitektur masjid Demakan sampai sekarang masih dilestarikan oleh masyarakat KabupatenDemak.
\end{abstract}

Kata Kunci: arsitektur, masjid, Demakan

\begin{abstract}
This research is motivated by the existence of the Great Mosque of Demak which is the first mosque in the Demak Regency. The mosque, which was founded in 1479 AD, has a unique mosque architecture. The uniqueness of the architecture of the mosque is carried out indepth research so that it becomes a reference in building other mosques in Demak Regency. The architecture of this mosque has maintained its local wisdom up to now. The purpose of this study is to identify, formulate the architecture of the Demakan mosque as one of the preserved mosque architectures in the Demak Regency. The method used in this research is a descriptive qualitative method. The method of data collection is done by field surveys. This research uses a qualitative approach and is an exploratory study. This type of research is descriptive in that it analyzes and presents facts systematically so that it is easy to understand and infer. The data collection through observation, in-depth interviews with a number of informants, and literature study. The results of the study can be formulated that the local wisdom of the mosque architecture of Demakan includes: (1) spatial planning, namely the main prayer room, foyer, and other additional spaces; (2) The structure is supported by 4 saka teachers and 12 saka responders in the main prayer room and the structure is supported by 8 saka teachers and 28 respondent saka in the foyer room; and (3) The main prayer room is square with a overlapping roof and a rectangular porch with a pyramid roof. The architecture of the Demakan mosque is still preserved by the people of the DemakRegency.
\end{abstract}

Keywords: architecture, mosque, Demakan

(C) 2020 The Authors. Published by TALENTA Publisher Universitas Sumatera Utara Selection and peer-review under responsibility of Seminar Nasional Kearifan Lokal V 2020 p-ISSN: 2654-7031, e-ISSN: 2654-704X, DOI: 10.32734/ee.v3i1.854 


\section{Latar Belakang}

Masjid yang berkembang tumbuh di Kabupaten Demak sejalan dengan pertambahan umat penganut Agama Islam. Agama Islam disebarkan oleh para wali yang diketahui dengan istilah Walisanga. Masjid merupakan representasi dari umat Islam yang melahirkan serta memakmurkannya[1]. Masjid digunakan bagaikan tempat berkumpul serta melaksanakan ibadah shalat secara berjamaah dengan tujuan tingkatkan solidaritas serta silaturahmi di golongan kalangan muslimin[2]. Masjid dikala ini dibentuk lebih banyak sebab dipengaruhi oleh faktor- faktor globalisasi penyebaran Islam, geografi, hawa setempat serta budaya lokal[3].

Sebutan arsitektur Demakan pada bangunan masjid berasal dari keberadaan Masjid Agung Demak di Kabupaten Demak yang pada masa sekarang ini sudah jadi cagar budaya serta dilestarikan. Masjid yang sudah berdiri semenjak tahun 1479 Meter[4] ini mempunyai arsitektur masjid yang unik sehingga arsitektur Masjid Agung Demak jadi patron untuk masjid model Demakan pada masa selanjutnya[5]. Wujud arsitektur masjid Demakan ialah prototipe untuk arsitektur masjid yang dibentuk pada masa sesudahnya baik yang sifatnya masih tradisional ataupun masjid- masjid yang mempunyai warna modern dengan penampilan wujud atap tumpang[6].

Kekhasan arsitektur masjid Demakan ini membagikan pengaruh kepada arsitektur masjid lain di Kabupaten Demak. Tiap desa/ kelurahan di Kabupaten Demak mempunyai masjid jami' merupakan masjid yang digunakan buat shalat berjamaah 5 waktu serta shalat jum' at[7]. Arsitektur masjid Demakan ini ialah peninggalan arsitektur masjid yang butuh dipertahankan serta dilestarikan. Keberadaan arsitektur masjid ini mulai tergerus terdapatnya arsitektur masjid yang lain semacam arsitektur dari Arab, India serta sebagainya. Riset ini bertujuan buat mengenali serta merumuskan arsitektur masjid Demakan di KabupatenDemak.

\section{Landasan Teori}

Masjid Agung Demak didirikan oleh para wali yang diketahui dengan walisanga yang menyebarkan agama Islam di Tanah Jawa[8]. Wujud Masjid Agung Demak dipengaruhi oleh budaya warga Jawa( Hindu, Budha, animisme serta dinamisme), sehingga Masjid Agung Demak tercantum dalam jenis Masjid Jawa. Pada tahun 1947, periset Belanda Gram. F. Pijper dalam[9] mengatakan kalau jenis wujud masjid di Indonesia berasal dari Masjid Jawa. Baginya terdapat 6 kepribadian universal jenis Masjid Jawa tersebut ialah: denah berupa bujur sangkar; lantainya langsung terletak pada fundamen yang masif ataupun tidak mempunyai kolong lantai, sebagaimana rumah- rumah vernakular Indonesia ataupun tempat ibadah berdimensi kecil semacam langgar( Jawa), tajug( Sunda), serta bale( Banten); atap tumpang dari 2 sampai 5 tumpukan yang menguncup ke satu titik di puncaknya; memiliki ruang bonus pada sebelah Barat ataupun Barat Laut buat mihrab; ada beranda baik pada sebelah depan( Timur) ataupun samping yang biasa diucap surambi ataupun siambi( Jawa) ataupun tepas masjid( Sunda); mempunyai ruang terbuka yang mengitari masjid dikelilingi pagar pembatas dengan satu pintu masuknya di bagian muka sebelah Timur. Guna dari serambi beranda tidak cuma bagaikan perpanjangan dari wilayah berdoa( ruang utama sholat) namun kerap buat mengakomodasi aktivitas semacam tempat pertemuan, perayaan Islam, serta lain- lain. Warga Jawa masih menyangka doa bagaikan aktivitas sakral yang membutuhkan tempat spesial serta terpisah dari aktivitas sosial[9].

Masjid Agung Demak tercantum tipikal masjid tradisional Jawa mempunyai identitas universal seperti berikut: mengenakan material kayu, beratap tumpang, ada memolo( hiasan dari puncak atap yang diadaptasikan dari tradisi Hindu), mempunyai tempat wudlu, serambi/ pendopo, pawestren( ruang shalat perempuan), pagar/ gerbang serta makam[10]. Dalam aspek tipologi, tradisionalitas wujud dasar arsitektur masjid biasanya diperlihatkan dengan bentuk- bentuk denah persegi/ bujursangkar, mempunyai serambi di muka bangunan. Bagian utama merupakan bujursangkar dalam, yang umumnya mempunyai 4 kolom( saka guru) buat menunjang atap[1]. Bagian utama ialah ruang berarti bagaikan ruang tempat manusia bersujud kepada Tuhan( sakral)[11]. Tradisionalitas tipologi wujud dasar atap umumnya diperlihatkan dengan wujud atap tajug dengan memolo di puncak atap ataupun meru sebab pengaruh Hindu[1]. Bangunan ini kerap dikira menyamai bangunan wantilan yang ada pada taman jaba sisi lingkungan pura, ataupun di bencingak lingkungan puri di Bali. Atap Masjid Agung Demak berupa tajug susun telu dengan sudut kemiringan atap terus menjadi terjal ke atas. Atap terbawah bersudut $33^{\circ}$ dengan akumulasi atap emper bersudut $21^{\circ}$, tengah bersudut $41059^{\prime} 13^{\prime}$ ' serta paling atas bersudut 49 33' 55' [12]. Masjid Agung Demak muncul dengan meresap bentuk- bentuk lokal serta unsur- unsur, yang menyebabkan wujud sinkretisme serta bersinambung hingga saat ini[13]. 
Masjid Agung Demak ialah salah satu kekayaan intelektual dari peninggalan budaya yang butuh dilestarikan. Keberadaan Masjid Agung Demak sudah jadi ikon serta bukti diri Kabupaten Demak. Bukti diri berarti kesamaan serta kesatuan yang menampilkan karakteristik khas serta keunikan yang menopang secara berkesinambungan([14];[15];[16]). Kearifan lokal jadi bagian berarti dalam memperkenalkan bukti diri wilayah itu sendiri[17]. Kearifan lokal yang terdapat pada bangunan masjid ini ialah perihal yang memastikan bukti diri, harkat serta martabat manusia dalam sesuatu komunitas[18].

Kearifan lokal merupakan tradisi fisik- budaya, serta secara turun- temurun yang mendasari pembentukan bangunan dan area sekitarnya[17]. Proses terbentuknya kebudayaan di Indonesia sudah menetapkan komponen faktor budaya yang berkembang serta tumbuh dalam kehidupan warga, semacam agama, bahasa, beragam wujud kesenian, norma, pengetahuan, ekonomi, perlengkapan budaya mukim[19]. Dalam bidang arsitektur, kebudayaan ini menciptakan artefak berbentuk macam bangunan dengan gunanya pada masing-masing hunian, pendopo, tempat sembahyang (masjid), lumbung, serta lain- lain. Masjid Agung sudah ratusan tahun berdiri hingga sekarang ini dengan dasar kearifan lokal yang diikuti oleh bangunan masjid lain di Kabupaten Demak. Kearifan Lokal merupakan gagasan- gagasan setempat( local) yang bertabiat bijaksana, penuh kearifan, bernilai baik, yang tertanam jadi tradisi( ajeg) serta diiringi oleh warga dekat([20];[21]; 22];[17];[23]).

Arsitektur masjid Demakan ialah menyesuaikan diri bangunan terhadap lingkungann sekitarnya. Arsitektur masjid Demakan ialah cerminan kebijakan nenek moyang dalam mensiasati serta paham terhadap keadaan area sekitarnya. Sistem struktur masjid ini terefleksikan dari filosofi wujud serta guna bangunannya. Pemilihan konstruksi yang pas buat mensiasati ikatan antara sistem struktur atas serta struktur dasar jadi cerminan kearifan lokal yang bisa dibesarkan pada kehidupan modern[24]. Motivasi menggali kearifan lokal bagaikan isu secara universal merupakan buat mencari serta kesimpulannya, bila dikehendaki, menetapkan bukti diri bangsa, yang bisa jadi lenyap sebab proses persilangan dialektis ataupun sebab akulturasi serta transformasi yang sudah, lagi, serta hendak terus terjalin bagaikan suatu yang tidak terelakkan. Untuk kita, upaya menciptakan bukti diri bangsa yang baru atas dasar kearifan lokal ialah perihal yang berarti demi penyatuan budaya bangsa di atas dasar bukti diri daerah- wilayah Nusantara[25].

\section{Metode}

Tata cara dalam riset ini memakai pendekatan kualitatif serta eksplorasi. Ekpsplorasi merupakan suatu riset buat mencari karena ataupun hal- hal yang pengaruhi suatu. Riset eksplorasi dikira lebih jelas serta detil dalam mendapatkan kenyataan dalam mengenali sesuatu fenomena sosial[26]. Ada pula pendekatan kualitatif digunakan buat menganalisis terhadap dinamika ikatan antar fenomena yang diamati dengan memakai logika ilmiah. Riset ini bertabiat deskriptif, ialah menganalis serta menyajikan kenyataan secara sistematik sehingga bisa lebih gampang buat dimengerti serta disimpulkan. Riset deskriptif menggambarkan secara sistematik serta akurat kenyataan mengenai populasi ataupun bidang tertentu, dalam hal ini tentang kearifal lokal pada arsitektur masjid Demakan. Ada pula pengambilan informasi lewat observasi, wawancara mendalam pada beberapa informan, serta riset pustaka

\section{Hasil danPembahasan}

Keberadaan arsitektur Masjid Agung Demak dianalisis berdasarkan analisis tata ruang, atap dan struktur konstruksi masjid.

\subsection{Analisis TataRuang}

Berdasarkan analisa peneliti dan didukung beberapa literatur yang ada, maka tata ruang Masjid Agung Demak berawal dari sebuah panepen. Panepen belum diberi nama masjid pertimbangannya sebagian besar masyarakat Jawa masih banyak yang beragama Hindu, Budha, kebatinan dan berbagai macam aliran kepercayaan, sedangkan para wali berkeinginan agar penduduk menganut agama Islam. Dalam perkembangan berubah menjadi masjid pesantren Glagahwangi pada tahun 1466 M dan pada tahun 1467 M berubah menjadi masjid Kadipaten Glagahwangi. Pada saat Raden Fatah dinobatkan menjadi sultan di Kasultanan Bintoro Demak pada tahun 1479 M,maka masjid mendapat tambahan serambi depan (alih fungsi pendopo Kasultanan Bintoro menjadi serambi masjid Demak) dan Dampar Kencono dialih fungsikan menjadi mimbar masjid Demak. 
Berdasarkan arsip takmir Masjid Agung Demak, ada tiga tahap pembangunan Masjid Demak semasa walisanga abad XV : Prasasti pertama/Candra Sengkala berbunyi "Nogo Mulat Saliro Wani" diartikan cikal bakal berdirinya Masjid bertarih 1388 Saka (=1466 M) sewaktu Raden Jimbun/Raden Kasan/Raden Fattah/Raden Patah berguru di Pesantren Glagahwangi pimpinan Sunan Ampel). Prasasti kedua Candra Sengkala berbunyi “Kori Trus Gunaning Janmi," diartikan tahun 1399 Saka (=1477M), rehabilitasi dan perluasan Masjid Kadipaten, sewaktu Raden Fatah menjabat Adipati Natapraja di Glagahwangi. Prasasti Ketiga/Candra Sengkala Memet, berbunyi “Sariro Sunyi Kiblating Gusti” bermakna tahun 1401 Saka (=1479 M), sewaktu Raden Fatah menduduki tahta kerajaan Islam I di Pulau Jawa, Masjid dipugar, direnovasi sebagai Masjid Kasultanan Bintoro, Demak.

Pada tahun $1804 \mathrm{M}$ dibangunlah pawestren sebagai tempat salat wanita yang terletak di sebelah Selatan ruang utama masjid. Sedangkan pada tahin 1924 M Sumur dan menara air serta renovasi tempat wudlu yang terletak di kanan kiri masjid (Tabel 1).

Tabel 1. Ruang Masjid Agung Demak Berdasar Kesejarahan

\begin{tabular}{llll}
\hline \multicolumn{1}{c}{ No } & \multicolumn{2}{c}{ Tahun } & \multicolumn{1}{c}{ Keterangan } \\
\hline Ruang Utama & - & Tempat ibadah \\
\hline 1 & Panepen & $1466 \mathrm{M}$ & Masjid pesantren Glagahwangi \\
\hline 2 & Ruang Sholat Utama & $1467 \mathrm{M}$ & Menjadi masjid Kadipaten Glagahwangi \\
& & $1479 \mathrm{M}$ & Menjadi masjid Kasultanan Bintoro \\
\hline 3 & Serambi depan & $1479 \mathrm{M}$ & Pendopo Kasultanan Bintoro dipindahkan/dialihfungsikan menjadi serambi Masjid \\
\hline Ruang/bangunan Tambahan : & & Agung Demak \\
\hline 1 & Regol dan pagar & $1804 \mathrm{M}$ & Gapura dan pagar depan \\
\hline 2 & Pawestren & $1804 \mathrm{M}$ & Tempat sholat untuk wanita \\
\hline 3 & Tratag rambat & $1885 \mathrm{M}$ & Bangunan penghubung regol dengan serambi masjid \\
\hline 4 & Ruang wudlu & $1924 \mathrm{M}$ & Sumur, menara air dan tempat wudlu di kanan kiri masjid \\
\hline 5 & Menara & $1932 \mathrm{M}$ & Menara adzan konstruksi baja \\
\hline 6 & Bangunan Depan & $1964 \mathrm{M}$ & $\begin{array}{l}\text { Pembongkaran regol, tratag rambat, tangki air, gedung sekolah Islam, KUA, } \\
\text { rumah penduduk di Kauman gang I }\end{array}$ \\
\hline & & & \\
\hline
\end{tabular}

Berdasarkan kesejarahan, tata ruang arsitektur masjid Demakan meliputi ruang utama salat dan serambi masjid. Ruang lain merupakan ruang tambahan yang disesuaikan dengan kebutuhan dan areal masjid. Ruang tambahan meliputi pawestren (ruang sholat wanita), ruang wudhu dan ruang tambahan lainnya (Gambar 1). 


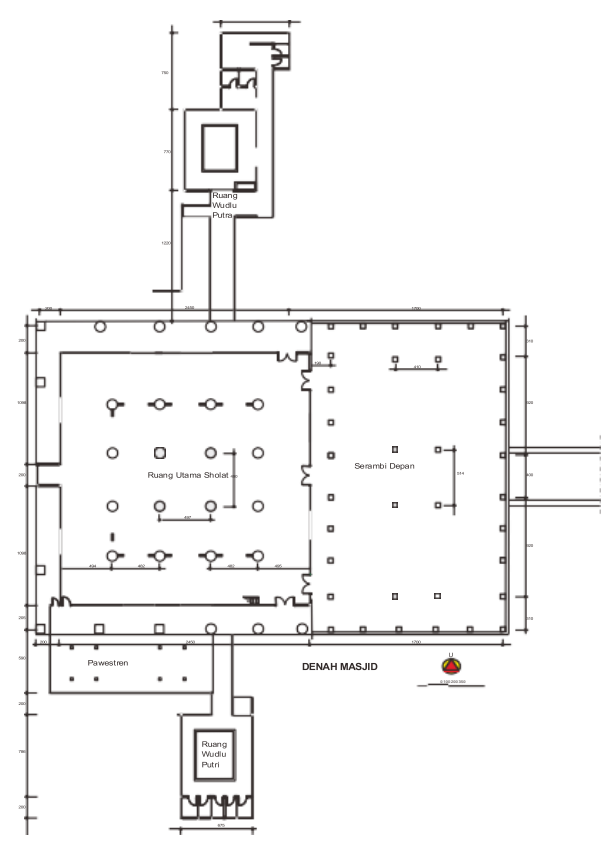

a

(a) Denah Masjid Agung Demak saatini

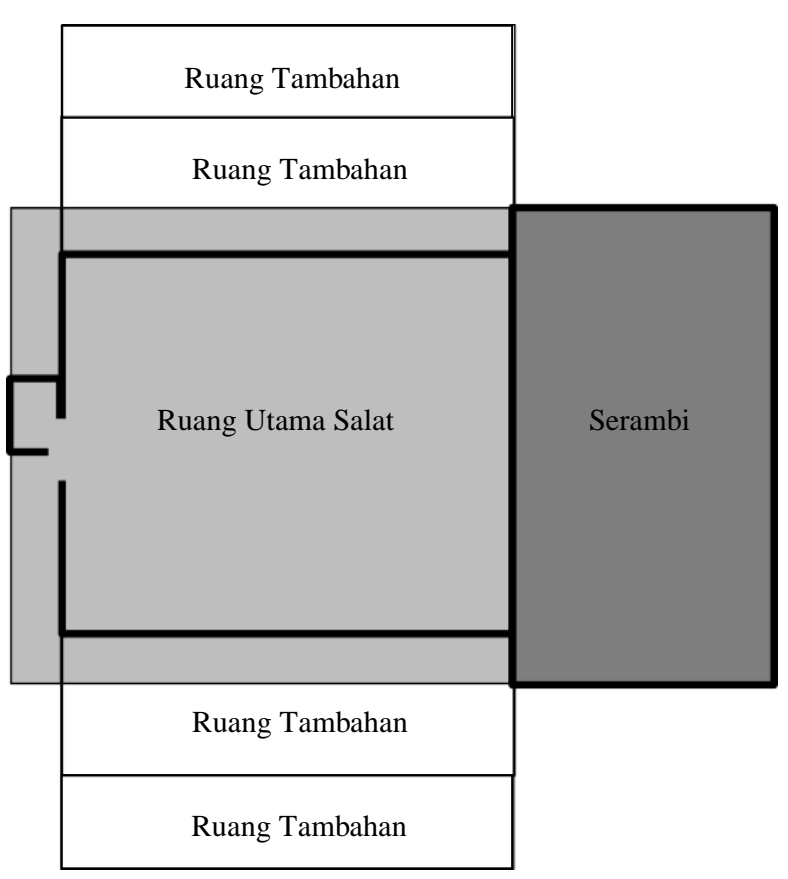

(b) Tata Ruang Arsitektur MasjidDemakan

Gambar 1. Denah dan tata ruang Masjid agung Demak

Sepanjang riwayatnya, Masjid Agung Demak sedikitnya 16 kali dipugar. Pertama kali oleh Raja Mataram Paku Buwono I, pada 1710. Ia mengganti atap sirap yang rapuh (Gambar 2).

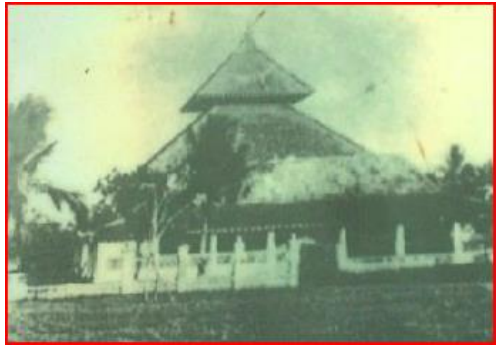

Th1800M

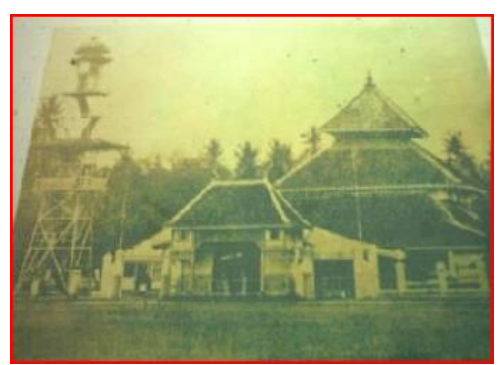

Th1962M

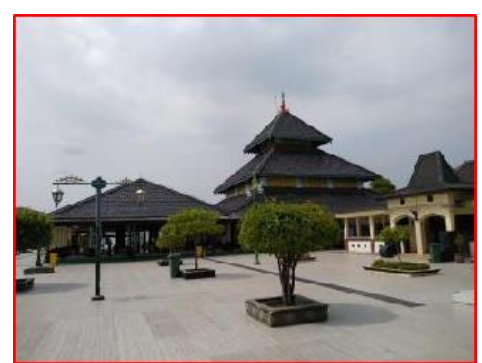

Saat Ini

Gambar 2. Tampak Masjid AgungDemak

Sumber : Museum Masjid Agung Demak

\subsection{AnalisisAtap}

Ruang utama salat arsitektur masjid Demakan menggunakan atap tajug tumpang 3 (tiga). Ruang serambi menggunakan atap limasan. Penggunaan atap tajug dan limasan ini menjadi ciri khas arsitektur masjid Demakan. Kedua atap ini menjadi prototipe yang diikuti oleh masjid lain sesudah masa Masjid Agung Demak berdiri. Atap tajug bersusun tiga mirip pura Hindu ini menunjukkan untuk menjadi pemeluk agama Islam yang sempurna supaya memiliki : (1) Iman adalah kepercayaan di dalam hati yang dilahirkan dengan tulisan atau ucapan dan dilaksanakan dengan gerakan semua anggota badan; (2) Islam artinya kaffah yaitu semua tingkah laku perbuatan dan ucapannya sudah menunjukkan tanda-tranda sebagai muslim yang taat; dan (3) Ikhsan ialah orang mukmin, muttaqin atau taqwa, hidupnya banyak digunakan untuk kepentingan akhirat dan tidak mementingkan urusan dunia [27]. 
Atap untuk tritisan Utara dan Selatan menggunakan perpanjangan dari atap tajug. Tritisan di sebelah Barat dan atap mihrab menggunakan perpanjangan dari atap tajug. Teritisan di sebelah Timur berhubungan langsung dengan atap limasan membentuk talang yang ditopang dengan kolom. Penggunaan teritisan yang memiliki lebar besar, maka perpanjangan atap tajug ini ditopang dengan kolom penyangga.

\subsection{Analisis Struktur dan Konstruksi}

Konstruksi Masjid Agung Demak menggunakan struktur yang terbuat dari kayu. Luas ruang utama salat masjid ini berukuran besar $24 \mathrm{~m}$ x $24 \mathrm{~m}$ sehingga penggunaan kayu dalam struktur masjid ini memiliki keterbatasan. Panjang kayu yang tidak mencukupi dilakukan sambungan dan diklem. Struktur ruang utama salat menggunakan saka penanggap sebagai penyangga atap tajug tumpang paling bawah. Atap tumpang tengah menggunakan kuda- kuda dan setengah kuda-kuda. Atap tajug tumpang paling atas hanya menggunakan blandar dan penegak untuk menopang atap.

Struktur ruang utama masjid ditopang oleh 4 saka guru. Salah satu saka guru dikenal dengan saka tatal yang merupakan saka guru sambungan antara kayu-kayu kecil utuh membentuk saka tatal setinggi $6 \mathrm{~m}$ sehingga mendapatkan ketinggian menyambung dengan kayu saka lain yang utuh menjadi $17 \mathrm{~m}$. Struktur saka tatal ini kuat menopang beban atap paling atas. Keempat saka guru ini merupakan karya empat wali dari walisanga. Susunan formasi tata letak saka guru adalah : bagian Barat Laut : Sunan Bonang (Tuban), bagian Barat Daya : Sunan Gunung Jati (Cirebon), bagian Tenggara : Sunan Ampel (Surabaya) dan bagian Timur Laut : Sunan Kalijaga (Kadilangu Demak) yang lebih dikenal dengan Saka Tatal [28]. Ruang serambi masjid ditopang 8 saka guru dan 28 saka penanggap. Dalam beberapa analisis yang dilakukan dapat dilihat dari tahap awal dan tahap penambahan yang menghasilkan rumusan arsitektur masjid Demakan. Hasil analisis arsitektur masjid Demakan (Tabel 2).

Tabel 2. Analisis Arsitektur Masjid Demakan

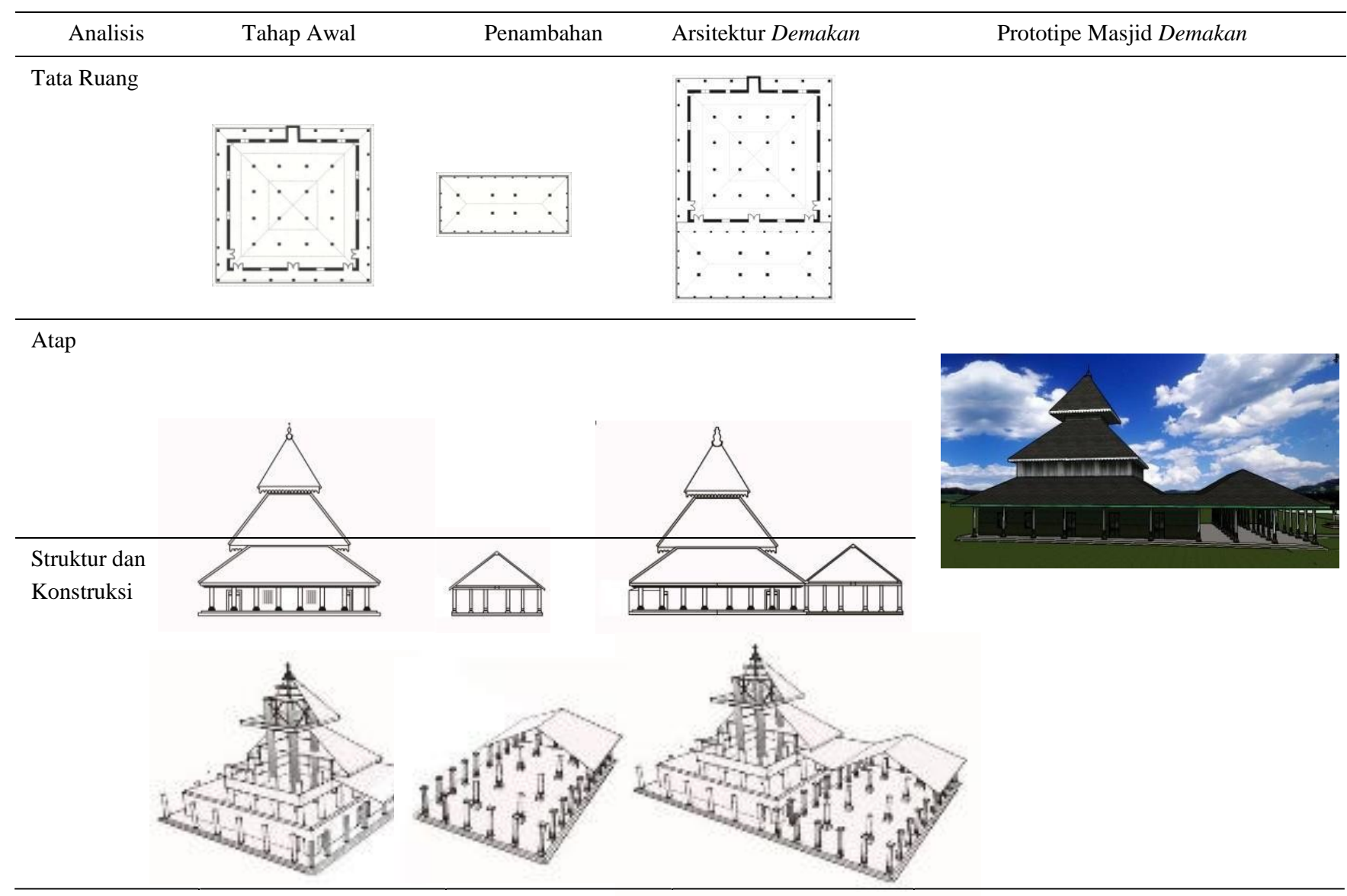


Masjid Agung Demak memiliki arsitektur yang sampai sekarang masih terpelihara dengan baik. Kearifan lokal arsitektur masjid Demakan ini dapat diungkap pada atap masjid, struktur dan konstruksi masjid serta tata ruangnya (Gambar 3).

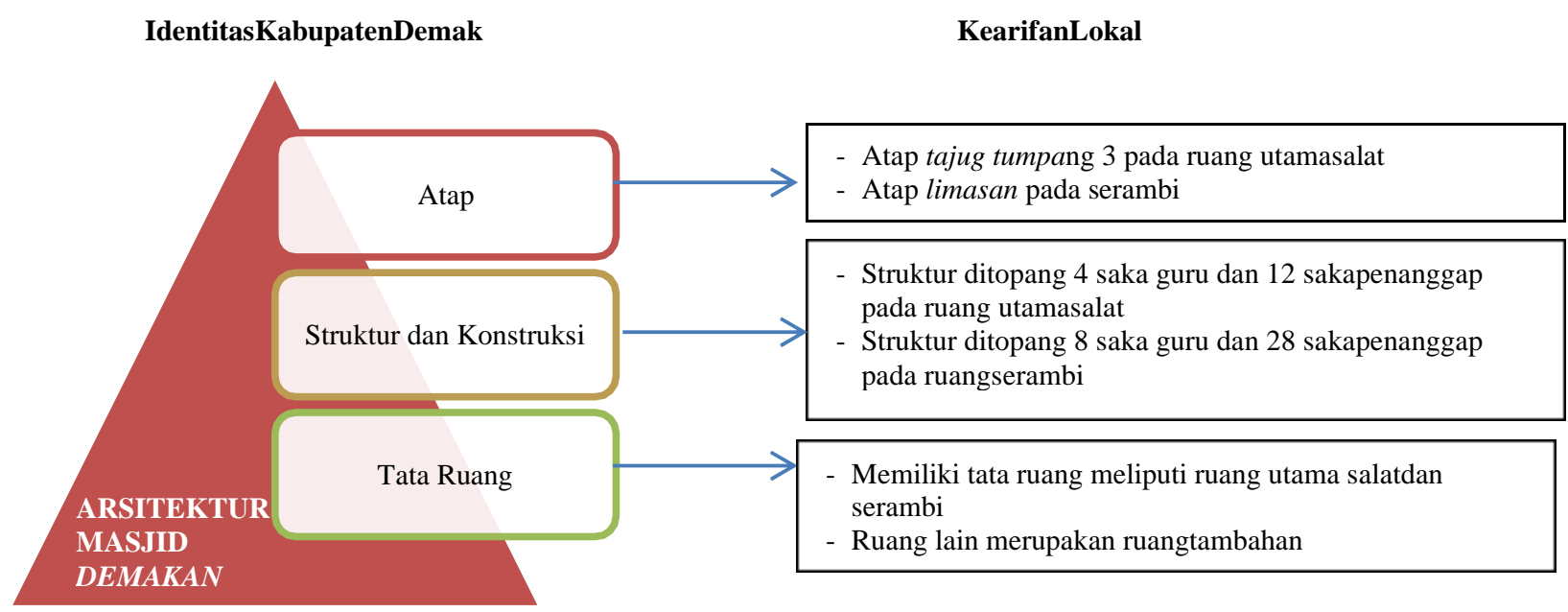

Gambar 3. Kearifan lokal arsitektur masjid Demakan

\section{Kesimpulan}

Penelitian ini memberikan pemahaman arsitektur masjid Demakan merupakan arsitektur Masjid Agung Demak yang sampai sekarang masih ada dan dilestarikan oleh masyarakat Kabupaten Demak. Pelestarian masjid ini diperkuat dengan masuknya bangunan Masjid Agung Demak menjadi salah satu bangunan cagar budaya. Keberadaan masjid yang sudah ratusan tahun memberikan pengetahuan baru adanya kearifan lokal yang masih dipertahankan dalam bangunan masjid. Kearifan lokal yang adapatasi terhadap lingkungan sekitarnya jaman dulu dan masih diikuti oleh masyarakat sampai sekarang dalam membangunmasjid.

Kearifan lokal arsitektur masjid Demakan meliputi : (1) tata ruang yakni ruang utama salat, serambi dan ruang tambahan lain; (2) Struktur ditopang 4 saka guru dan 12 saka penanggap pada ruang utama salat dan struktur ditopang 8 saka guru dan 28 saka penanggap pada ruang serambi; dan (3) Ruang utama salat berbentuk bujur sangkar dengan atap tajug tumpang 3 dan serambi berbentuk persegi panjang dengan ataplimasan

Dalam upaya melestarikan arsitektur masjid Demakan ini peran serta Pemerintah Daerah dan masyarakat diperlukan unuk mempertahankan arsitektur masjid Demakan ini dalam perancangan masjid di Kabupaten Demak.

\section{Referensi}

[1] Barliana,M.S.(2004)“TradisionalitasdanModernitasTipologiArsitekturMasjid”JurnalDimensi TeknikArsitektur, 32:110-118.

[2] Ayub, M.E. (1996) "Manajemen Masjid : Petunjuk Praktis bagi Para Pengurus" Gema Insani Press,Jakarta.

[3] Stiglitz, Joseph E. (2007) "Making Globalization Work: Menyiasati Globalisasi Menuju Dunia yang Lebih Adil. Bandung”Mizan.

[4] Sumalyo, Y. (2000) “Arsitektur Masjid dan Monumen Sejarah Muslim” Gadjah Mada University Press,Jogjakarta.

[5] Roesmanto, T. (2007) "Pemanfaatan Potensi Lokal dalam Arsitektur Indonesia" Pidato Pengukuhan Jabatan Guru Besar dalam llmu Perkembangan Arsitektur pada Fakultas Teknik Universitas Diponegoro, Badan Penerbit Universitas Diponegoro,Semarang.

[6] Ashadi (2002) “Masjid Agung Demak Sebagai Prototipe Masjid Nusantara: Filosofi Arsitektur” Jurnal Arsitektur - NALARs, Arsitektur Teknik MuhammadiyahJakarta.

[7] Ismail, M.F. (2003) “Peranan Masjid” Penerbit Darul Nu’man, KualaLumpur.

[8] Tarwilah (2006) "Peranan Walisongo dalam Pengembangan Dakwah Islam” Ittihad Jurnal Kopertis Wilayah XI Kalimantan, 4 :81-102

[9] Budi, BS. (2004) "A Study on the History and Development of the Javanese Mosque Part 1: A Review of Theories on the Origin of the Javanese Mosque" Journal of Asian Architecture and Building Engineering 3 :189-195.

[10] Setiabudhi, B. (2000) "Menelusuri Arsitektur Masjid di Jawa, dalam Mencari Sebuah Masjid” Masjid 2000,Bandung.

[11] Kusyanto, M. (2007) "Konsep Dasar Arsitektur Tata Ruang Rumah Tinggal Tradisional Jawa Tengah Pada Perkembangan Tata Ruang Masjid Kadilangu Demak Dari Awal Berdiri Sampai Sekarang” Jurnal Teknik Sipil dan Perencanaan, Universitas Negeri Semarang 9 : $65-76$. 
[12] Anom, JGN, dkk. (1986) "Laporan Pemugaran Masjid Agtmg Demak, Proyek Pemugaran dan Pemeliharaan Masjid Agung Demak Bantuan Presiden 1985-1986" K-Offset, Yogyakarta.

[13] Ashadi. Antariksa dan Salura, P. (2016) "Syncretism in Architectural Forms of Demak Grand Mosque" Journal of Applied Environmental and Biological Sciences, 5 (11) :26-30.

[14] Abel, Chris. (1997) “Architecture and Identity”. Singapore Architectural Press. Adimihardja, Kusnaka. 2008. Dinamika Budaya Lokal. Bandung, CV.Indra Prahasta + LBPB.

[15] Hasan, Izziah. (2009) “Architecture and the Politics of Identity in Indonesia” Adeleide, University of AdeleidePress, Disertasi.

[16] Anwar, Widya Fransiska F. (2011) "Method to Elicit Local Wisdom in Perceiving the Transformation of Historical Living Environment". University TeknologiMalaysia.

[17] Antariksa (2009) “Kearifan Lokal dalam Arsitektur Perkotaan dan Lingkungan Binaan” Seminar Nasional Kearifan Lokal (Local Wisdom) dalam Perencanaan dan Perancangan Lingkungan Binaan. Universitas MerdekaMalang

[18] Geertz, C. (1992) “Kebudayaan dan Agama” Yogyakarta, KanisiusPress.

[19] Meliono, Irmayanti (2011) "Understanding the Nusantara Thought and Local Wisdom as an Aspect of the Indonesian Education”Tawarikh, International Journal for Historical Studies, 2(2) 2011

[20] Keraf, AlexanderSonny(2002)“EtikaPengelolaanSumberDayaAlamdanLingkunganHidup”Jakarta,UnikaAtmaJaya.

[21] Gobyah,IKetut(2003)“BerpijakPadaKearifanLokal”.http://www.balipost.co.id/BALIPOSTCETAK/2003/9/17/bd3.htm

[22] Ridwan, N. A. (2007) “Landasan Keilmuan Kearifan Lokal. Purwokerto” P3M STAIN, IBDA 5 (1):27-38.

[23] Sartini (2009) "Menggali Kearifan Lokal Nusantara - Sebuah Kajian Filsafati” http://dgiindonesia.com/menggali-kearifan-lokal-nusantarasebuah-kajian-filsafati/

[24] Ibrahim, William dan Nandang (2011) “Arsitektur Tradisional Kenali: Salah Satu Kearifan Lokal Daerah Lampung”. UniversitasLampung, Jurnal Rekayasa 15 (1)

[25] Sayuti, S.A. (2005) “Menuju Situasi Sadar Budaya: Antara Yang Lain” dan Kearifan Lokal. http://www.semipalar.net.(Diakses 30 Desember2019).

[26] Gobyah (2005) "Domestic Architecture and The Use of Space” Cambridge University Press.Cambridge

[27] Kusyanto, M. (2008) “Studi Keterkaitan Arsitektur Masjid agung Demak Dengan Arsitektur Masjid-masjid Lain Di Kabupaten Demak” Tatal 4 (1) Kusyanto, M. (2016) "Karakteristik Sistem Struktur Ruang Utama Masjid Agung Demak" Prosiding Temu Ilmiah IPLBI:h-079-08 